\title{
PENGEMBANGAN BAHAN AJAR KETERAMPILAN BERBICARA INTERAKTIF BAGI MAHASISWA
}

\author{
Ribut Wahyu Eriyanti \\ Fakultas Keguraun dan Ilmu Pendidikan \\ Universitas Muhammadiyah Malang \\ ributwahyueriyanti@yahoo.com
}

\begin{abstract}
Abstrak: Penelitian ini bertujuan untuk menghasilkan bahan ajar keterampilan berbicara interaktif bagi mahasiswa S1 Pendidikan Bahasa dan Sastra Indonesia UMM. Model penelitian yang digunakan adalah penelitian pengembangan model Recursive, Reflective Design and Development (R2D2) menurut Willis yang dipadukan dengan model Research and Development (R and D) menurut Brog and Gall. Hasil penelitian ini menunjukkan bahwa materi bahan ajar keterampilan berbicara yang dibutuhkan dikategorikan ke dalam dua jenis, yakni materi yang bersifat konsep teoritis sebagai bekal pemahaman konsep dasar keterampilan berbicara dan materi yang bersifat keterampilan yang dikategorikan berdasarkan pada konteks situasi komunikasi mulai dari bahan pembelajaran keterampilan berbicara pada situasi informal, interpretatif, formal, dan dramatik.
\end{abstract}

Kata kunci: bahan ajar, berbicara, mahasiswa, pembelajaran

Abstract: This study aimed at producing teaching material of interactive speech for under graduate students of Indonesian Language and Literature of Muhammadiyah University of Malang. Research model applied in this study was the development of Recursive Model, Reflective Design and Development (R2D2) according to Willis which was combined with Research and Development model ( $R$ and $D)$ according to Brog and Gall. The result of the study showed that teaching material of speaking skill was categorized into two, namely material which included theoretical concept as basic concept comprehension of speaking skill and material which is categorized as skill based on communication situation context starting from speaking skill learning in informal, formal interpretative and dramatic situation.

Keyword: teaching material, speaking, university students, learning

\section{PENDAHULUAN}

Pembelajaran merupakan proses interaksi peserta didik dengan pendidik dan sumber atau bahan ajar tertentu dalam lingkungan pendidikan untuk mencapai tujuan pendidikan. Konsep pembelajaran tersebut menempatkan peserta didik bukan sebagai objek pembelajaran, melainkan sebagai subjek pembelajaran yang secara aktif dan kreatif melaksanakan interaksi dengan pendidik dan bahan ajar, serta peserta didik yang lain.

Salah satu kualifikasi lulusan jenjang studi Strata 1 (jenjang kualifikasi 6) menurut Kerangka Kualifikasi Nasional Indonesia (KKNI) adalah "Mampu mengaplikasikan bidang keahliannya dan memanfaatkan ilmu pengetahuan, teknologi, dan/atau seni pada bidangnya dalam penyelesaian masalah serta mampu beradaptasi terhadap situasi yang dihadapi” (Perpres Nomor 8 Tahun 
2012). Mengacu pada KKNI tersebut, Asosiasi Program Studi Bahasa dan Sastra Indonesia telah merumuskan capaian pembelajaran Program Studi Pendidikan Bahasa Indonesia, Strata 1 pada aspek pengetahuan antara lain adalah "menguasai konsep-konsep dasar kebahasaan dan kesastraan, keterampilan berbahasa dan bersastra, pembelajaran bahasa dan sastra, penelitian bahasa dan sastra, serta penelitian pendidikan bahasa dan sastra;". Pada aspek keterampilan umum, salah satu capaian pembelajaran untuk mahasiswa Program Sarjana adalah "mampu menerapkan pemikiran logis, kritis, sistematis, dan inovatif dalam konteks pengembangan atau implementasi ilmu pengetahuan dan teknologi yang memperhatikan dan menerapkan nilai humaniora bidang pendidikan bahasa dan sastra Indonesia". Adapun pada aspek keterampilan khusus dirumuskan salah satu capaian pembelajaran yang diharapkan adalah "mampu berbahasa dan bersastra Indonesia, secara lisan dan tulisan dalam konteks keseharian/ umum, akademis, dan pekerjaan; serta mampu menggunakan salah satu bahasa daerah.

Sesuai dengan rumusan capaian pembelajaran tersebut, capaian pembelajaran program sarjana pada aspek pengetahuan di antaranya adalah, "menguasai konsep-konsep dasar kebahasaan dan kesastraan, keterampilan berbahasa dan bersastra, pembelajaran bahasa dan sastra, penelitian bahasa dan sastra, serta penelitian pendidikan bahasa dan sastra"; sedangkan salah satu standar kompetensi lulusan aspek keterampilan khusus adalah, "mampu berbahasa dan bersastra Indonesia, secara lisan dan tulisan dalam konteks keseharian/ umum, akademis, dan pekerjaan; serta mampu menggunakan salah satu bahasa daerah".

Bertolak dari konsep pembelajaran dan capaian pembelajaran pada jenjang Strata 1 Pendidikan Bahasa dan Sastra Indonesia, tugas pendidik adalah memfasilitasi peserta didik untuk mengembangkan potensi dirinya agar dapat berkembang secara optimal. Dalam hal ini, pendidik bukanlah satu-satunya sumber pembelajaran karena masih ada beberapa sumber belajar lain yang dapat diberdayakan secara optimal untuk mengembangkan potensi peserta didik, yakni bahan ajar.

Paradigma pembelajaran tersebut menempatkan bahan ajar sebagai salah satu komponen pembelajaran yang sangat penting perannya dalam rangka memfasilitasi kegiatan belajar peserta didik. Melalui bahan ajar yang beragam dan bermakna, peserta didik akan dapat mengembangkan pengetahuan, kemampuan berpikir, dan daya kritis serta kreatifnya secara optimal terus-menerus.

Meskipun disadari bahwa peran bahan ajar sangat penting dalam pembelajaran, dalam praktik pembelajaran diketahui bahwa ketersediaan bahan ajar masih terbatas, terutama bahan ajar untuk mengembangkan keterampilan berbicara dalam bahasa Indonesia. Di sisi lain, bahan ajar yang tersedia, masih memiliki keterbatasan, di antaranya materi bahan ajar tersebut tidak disusun secara taksonomis, baik dari segi urutannya maupun cara penyajiannya. Penyajian isi materi bahan ajar yang ada, sebagian masih bersifat informatif dan eksplanatif. Bahkan, bahan ajar keterampilan berbicara yang tersedia masih cenderung memuat teori-teori tentang keterampilan berbicara (bersifat teoretis dan belum memberikan kesempatan peserta didik untuk berlatih mengasah keterampilannya). Bahan ajar "Pembelajaran Keterampilan Berbahasa dengan Pendekatan KomunikatifInteraktif(Ghazali, 2010) masih cenderung berisi konsep-konsep teoretis tentang pembelajaran keterampilan berbahasa. Demikian juga dengan buku "Terampil Berbicara, Teori dan Pedoman Penerapanannya" (Musaba, 2012) cenderung memaparkan konsep teoretis keterampilan berbicara.

Tidak jauh berbeda kondisinya dengan bahan ajar yang tersedia, perencanaan pembelajaran yang disusun oleh beberapa dosen di beberapa program studi atau jurusan pendidikan bahasa Indonesia juga cenderung kurang memfasilitasi peserta didik untuk 
mengembangkan kompetensi keterampilan berbicara secara nyata. Pada silabus matakuliah Berbicara Dialektis juga terlihat pokok bahasan yang direncanakan lebih banyak membahas konsep teoretis tentang teknik berbicara. Silabus matakuliah Pembelajaran Bebicara menunjukkan bahwa praktik pembelajaran bebricara baru dilaksanakan pada pertemuan ke-12 sampai dengan ke-15.

Akibat kondisi bahan ajar beserta pelaksanaan pembelajaran tersebut adalah masih kurang optimalnya capaian pembelajaran berbicara. Perkembangan kemampuan berbicara peserta didik masih belum berkembang optimal.

Berdasarkan gambaran tentang kondisi bahan ajar dan rencana pelaksanaan pembelajaran beserta dampaknya pada capaian pembelajaran mahasiswa, diperlukan bahan ajar keterampilan berbicara interaktif. Bahan ajar ini memberikan pengalaman dan pemahaman kepada peserta didik tentang pemakaian bahasa untuk berkomunikasi lisan secara nyata dan interaktif. Dengan demikian, diharapkan peserta didik dapat mengembangkan potensi berpikir dan berbahasanya secara optimal melalui berpraktik secara langsung. Di sisi lain, pemberian kesempatan peserta didik untuk saling memberikan komentar dapat mengembangkan daya kritis, kreatif, dan keberanian peserta didik untuk menggunakan bahasa dalam berkomunikasi secara terusmenerus. Dengan demikian, diharapkan potensi dan kompetensi berbahasa peserta didik dapat dikembangkan secara optimal dan komprehensif.

Berdasarkan latar belakang yang telah dipaparkan, disimpulkan bahwa permasalahan utama pembelajaran berbicara bagi mahasiswa Program Studi Pendidikan Bahasa Indonesia adalah terbatasnya bahan ajar untuk mengembangkan keterampilan berbicara bagi mahasiswa. Akibatnya, pelaksanaan pembelajaran keterampilan berbicara bagi mahasiswa belum dapat dilaksanakan secara efektif.

Berdasarkan kondisi objektiftersebut, tujuan penelitian ini adalah mengembangkan produk bahan ajar keterampilan berbicara interaktif bagi mahasiswa Program Studi Pendidikan Bahasa dan Sastra Indonesia yang dirancang selama dua tahun. Bahan ajar ini dirancang bersifat interaktif. Hal itu disesuaikan dengan karakteristik kompetensi yang dikembangkan melalui matakuliah keterampilan berbicara yang pragmatis. Hal itu sesuai dengan pendapat Littlewood (1984) bahwa dalam pembelajaran, peserta didik harus mampu memahami dan mengolah bahasa lisan terlebih dahulu sebelum mengembangkan kemampuan berbicara. Proses tersebut disebut sebagai proses konstruksi kreatif (Littlewood, 1984).

Pada model konstruksi kreatif, pendidik cenderung berperan sebagai fasilitator yang bertindak memfasilitasi peserta didik untuk mengkonstruksi pemahaman dan keterampilan berbicaranya dengan menyediakan konteks yang memungkinkan peserta didik memperoleh pengetahuan dan pengalaman langsung kegiatan berbahasa. Hal itu terlihat dari sintaks pembelajarannnya, yakni dimulai dari (1) penyediaan input berupa pengalaman langsung kegiatan berbahasa (eksposure), (2) pengolahan internal oleh peserta didik, (3) penyusunan sistem bahasa oleh peserta didik, dan (keluar ucapanucapan secara spontan. Dalam rangka penyediaan input bagi peserta didik itulah diperlukan bahan ajar interaktif.

Bahan ajar adalah semua yang digunakan oleh pendidik atau peserta didik untuk memfasilitasi belajar bahasa. Bahan ajar tersebut dapat berbentuk video, DVD, email, You Tube, kamus, buku tatabahasa, pembaca, lembar kerja atau fotokopi catatan. Bahan ajar juga dapat berupa surat kabar, paket makanan, foto, tuturan langsung oleh penutur asli suatu bahasa, tuturan atau penjelasan guru, tugastugas tertulis, diskusi kelompok secara langsung antar siswa (Tomlinson, 2011: 2). Hal senada juga dikemukakan oleh (Direktorat Sekolah Menengah Pertama, 2006: 4) bahwa bahan ajar merupakan materi pembelajaran (instructional materials) berupa pengetahuan (fakta, konsep, prinsip, prosedur), keterampilan, dan sikap yang 
harus dipelajari peserta didik dalam rangka mengembangkan kompetensi tertentu yang telah ditetapkan.

Termasuk ke dalam jenis materi fakta adalah nama-nama objek, peristiwa sejarah, lambang, nama tempat, nama orang, binatang. Termasuk ke dalam materi konsep adalah pengertian, definisi, ciri khusus, komponen atau bagian suatu objek. Yang termasuk ke dalam materi prinsip adalah dalil, rumus, adagium, postulat, teorema, atau hubungan antarkonsep yang menggambarkan hubungan, misalnya jika...., maka..., rumus dsb. Adapun materi jenis prosedur adalah bahan ajar yang berkenaan dengan langkah-langkah secara sistematis atau berurutan dalam mengerjakan suatu tugas. Misalnya langkah-langkah mengoperasikan peralatan, cara merawat tanaman, cara membuat minuman.

Materi keterampilan berupa praktik untuk melakukan sesuatu. Dalam dalam pembelajaran bebicara, materi keterampilan berbicara berupa kegiatan berpraktik langsung berbicara untuk berbagai tujuan dalam berbagai konteks.

Pengembangan bahan ajar merupakan kegiatan mempelajari dan praktik menghasilkan materi pembelajaran. Yang dikaji meliputi prinsip-prinsip dan prosedur merancang, mengimplementasikan, dan mengevaluasi materi pembelajaran bahasa (Tomlinson, 2011: 2 ). Bentuk kegiatan praktik pengembangan bahan ajar mengacu pada suatu kegiatan yang dilakukan penulis, pendidik, atau peserta didik untuk menyediakan sumber bahan bahasa, untuk mengeksploitasi sumber-sumber tersebut dengan berbagai cara untuk mengembangkan kompetensi peserta didik dan untuk menstimulasi belajar peserta didik, sehingga tujuan pembelajaran dapat tercapai (Tomlinson, 2011:2). Dengan kata lain, praktik pengembangan bahan ajar merupakan penyediaan informasi, pengalaman bahasa, yang didesain untuk pembelajaran bahasa.

\section{METODE}

Penelitian ini menggunakan model penelitian pengembangan dengan memadukan model Recursive, Reflective Design and Development atau (R2D2) (Willis, 1995) dan model R \& D (Gall, M.D; Gall, J.P., \& Borg, 2003). Model R2D2 memiliki tiga tahap pengembangan, yaitu (1) tahap pendefinisian, (2) tahap perancangan dan pengembangan, dan (3) tahap penyebarluasan atau desiminasi (Willis, 1995). Dengan demikian, pengembang memiliki keleluasaan dalam menentukan keputusan dan dapat meninjau kembali bahan ajar yang dikembangkan jika diperlukan. Pengembang juga memiliki kebebasan memilih urutan kegiatan pengembangan. Dalam proses pengembangan, pengembang melibatkan tim partisipatori secara ekstensif dalam setiap fase mulai dari fase perencanaan sampai dengan pengembangan.

Mengacu pada model pengembangan yang ditetapkan, data penelitian pada tahap I (tahun pertama) ini berbentuk kualitatif berupa tanggapan (komentar, saran, kritik) dari mahasiswa, dosen/ praktisi, dan pakar pada proses pendefinisian, perencanaan, dan pengembangan, yang dilakukan melalui kegiatan focus group discussion (FGD). Kegiatan FGD dilaksanakan dengan tujuan dapat diperoleh masukan bahan pengembangan bahan ajar keterampilan berbicara interaktif bagi mahasiswa Program Studi Pendidikan Bahasa dan Sastra Indonesia (PSPBSI). Bahan-bahan yang diperlukan meliputi substansi/isi bahan ajar, struktur/susunan bahan ajar, analisis lingkungan belajar, strategi pembelajaran yang diterapkan, dan media pembelajaran yang digunakan dalam penyajian bahan ajar (kemasan bahan ajar).

Di samping itu, data penelitian ini juga diperoleh dari hasil telaah silabus matakuliah keterampilan berbicara (keterampilan berbahasa lisan) dari dua perguruan tinggi negeri dan dua perguruan tinggi swasta. Sesuai dengan jenis data yang dikumpulkan, data kualitatif dianalisis secara kualitatif dengan menggunakan analisis domain, yaitu mengelompokkan data berdasarkan domain masalah penelitian. 


\section{HASIL DAN PEMBAHASAN}

\section{Hasil Penelitian}

Sesuai dengan masalah dan tujuan penelitian tahap I, hasil penelitian ini meliputi: substansi atau isi bahan ajar, struktur atau susunan bahan ajar, lingkungan belajar yang dibutuhkan, strategi pembelajaran yang diterapkan, dan media pembelajaran yang digunakan dalam penyajian bahan ajar.

\section{Substansi Bahan Ajar Keterampilan Berbicara}

Substansi bahan ajar ditetapkan dan dikembangkan berdasarkan hasil analisis data yang bersumber dari silabus, hasil FGD Tim Partisipatori, dan telaah capaian pembelajaran matakuliah keterampilan berbicara. Capaian pembelajaran matakuliah keterampilan berbicara dikembangkan mengacu pada rumusan kompetensi yang telah ditetapkan dalam lampiran Peraturan Menteri Riset, Teknologi, dan Perguruan Tinggi (Menristek Dikti) Nomor 44 Tahun 2015. Di dalam peraturan tersebut dinyatakan bahwa kompetensi keterampilan umum lulusan Program Sarjana adalah (1) mampu menerapkan pemikiran logis, kritis, sistematis, dan inovatif dalam konteks pengembangan atau implementasi ilmu pengetahuan dan teknologi yang memperhatikan dan menerapkan nilai humaniora sesuai dengan bidang keahliannya dan (2) mampu mengambil keputusan secara tepat dalam konteks penyelesaian masalah di bidang keahliannya berdasarkan hasil analisis informasi dan data, unjuk kinerja mandiri, bermutu, dan terukur (APROBSI, 2016: 8).

Bertolak dari kompetensi umum tersebut, Asosiasi Program Studi Pendidikan Bahasa dan Sastra Indonesia (APROBSI) telah bermufakat merumuskan kompetensi pengetahuan dan keterampilan khusus. Kompetensi pengetahuan yang dikembangkan pada peserta didik yang diperlukan untuk mencapai keterampilan berbicara adalah, "Menguasai konsep-konsep dasar kebahasaan dan kesastraan, keterampilan berbahasa dan bersastra, pembelajaran bahasa dan sastra, penelitian bahasa dan sastra, serta penelitian pendidikan bahasa dan sastra."

Kompetensi keterampilan khusus yang telah dirumuskan oleh Asosiasi Program Studi Pendidikan Bahasa dan Sastra Indonesia yang relevan dengan matakuliah keterampilan berbicara adalah, (1) mampu berbahasa dan bersastra Indonesia secara lisan dalam konteks keseharian/umum, akademis, dan pekerjaan dan (2) mampu mengapresiasi, mengekspresi, mengkreasi karya sastra Indonesia secara lisan (APROBSI, 2016: 11).

Mengacu pada capaian pembelajaran (CP), tujuan pembelajaran keterampilan berbicara pada PSPBSI adalah mahasiswa mampu (a) menguasai konsep dasar keterampilan berbicara (berbicara sebagai keterampilan berbahasa, tingkatan keterampilan berbicara, tujuan berbicara, jenis-jenis kegiatan berbicara, faktor penentu komunikasi bicara), (b) menyampaikan isi pesan, informasi, keinginan, perasaan, dan pengetahuan untuk berbagai tujuan komunikasi lisan menggunakan bahasa Indonesia secara baik dan benar.

Berdasarkan hasil telaah $\mathrm{CP}$, silabus, dan masukan hasil FGD diperoleh rancangan substansi materi bahan ajar keterampilan berbicara dikelompokkan ke dalam dua kategori. Kedua kategori materi tersebut meliputi (1) materi yang bersifat konseptual dan (2) materi yang bersifat keterampilan. Pertama, materi konseptual meliputi (a) hakikat berbicara, (b) proses komunikasi bicara, (c) tujuan berbicara, (d) jenis-jenis komunikasi bicara, (e) tingkatan keterampilan berbicara, (f) faktor penentu komunikasi bicara, dan (g) kiat bicara efektif. Materi konseptual diperlukan untuk mendukung pengembangan kompetensi keterampilan dan sikap.

Kedua, materi yang bersifat keterampilan dikategorikan berdasarkan pada konteks situasi komunikasi mulai dari bahan pembelajaran keterampilan berbicara pada situasi informal, interpretatif, formal, dan dramatik. (1) Kategori 
keterampilan berbicara informal adalah (a) percakapan dan (b) dialog. (2) Yang termasuk ke dalam kategori bebicara interpretatif meliputi (a) bercerita dan (b) membacakan naskah drama. (3) Berbicara formal meliputi (a) menyampaikan laporan, (b) menjelaskan proses dan prosedur, (c) berwawancara, dan (d) berdebat. Adapun yang termasuk kategori berbicara dramatik meliputi (a) bermain drama dan (b) bermain peran.

\section{Lingkungan Belajar dan Media yang Diperlukan}

Sesuai dengan isi materi yang telah dipaparkan, selanjutnya dilakukan pemilihan lingkungan belajar. Lingkungan belajar merupakan tempat atau suasana pembelajaran yang akan dilaksanakan dengan menggunakan bahan ajar ini. Sesuai dengan jenis-jenis kegiatan berbicara yang pada umumnya dilakukan oleh seseorang dalam situasi nyata, maka lingkungan belajar yang disediakan dalam pengembangan bahan ajar ini meliputi lingkungan sekolah, masyarakat, dan tempat kerja. Lingkungan sekolah diperlukan untuk penyajian bahan ajar yang bersifat keterampilan, yakni berbicara dalam situasi formal dan juga interpretatif. Lingkungan masyarakat diperlukan untuk penyajian bahan ajar keterampilan berbicara dalam situasi informal. Adapun tempat kerja diperlukan untuk penyajian bahan ajar keterampilan berbicara dramatik.

Sesuai dengan isi materi dan lingkungan belajar, diperlukan media pembelajaran yang mendukung pemanfaatan bahan ajar keterampilan berbicara interaktif. Media penyajian bahan ajar dalam penelitian ini berupa media cetak dan berbentuk video yang dikemas ke dalam Compact Disk (CD). Media cetak diperlukan untuk menyajikan bahan ajar berupa konsep teoritis keterampilan berbicara secara utuh, sedangkan media berbentuk video digunakan untuk menyajikan bahan ajar yang bersifat praktik/ pragmatik. Bahan-bahan tersebut meliputi modelmodel kegiatan berbicara yang dilatihkan kepada mahasiswa dilengkapi dengan tugas-tugas yang harus dilakukan oleh mahasiswa sebagai bentuk kegiatan berlatih berbicara. Dengan model yang disajikan, diharapkan mahasiswa memperoleh pengetahuan atau contoh konkrit pemakaian bahasa dalam berbagai tujuan komunikasi.

\section{Strategi Penyajian Bahan Ajar Keterampilan Berbicara}

Strategi penyajian bahan ajar merupakan representasi strategi pembelajaran yang diterapkan dalam pembelajaran. Pemilihan strategi pembelajaran dalam pengembangan bahan ajar ini didasarkan pada pendekatan pembelajaran yang diterapkan. Dalam hal ini terdapat tiga jenis pendekatan pembelajaran keterampilan berbahasa, yakni pendekatan struktural, pendekatan kognitif, dan pendekatan konstruktivistik. Dari ketiga pendekatan tersebut, yang diterapkan dalam pengembangan bahan ajar ini adalah pendekatan konstruktivistik.

Pendekatan konstruktivistik memandang peserta didik sebagai individu yang memiliki potensi untuk membangun pengetahuan melalui pengelaman yang diperoleh di lingkungan sekitarnya. Denagn pandangan tersebut, dalam pembelajaran, tugas pendidik adalah menciptakan kondisi atau memfasilitasi peserta didik agar dapat mengembangkan potensi dirinya secara optimal.

Berdasarkan asumsi tersebut, strategi pembelajaran yang diterapkan dalam pembelajaran adalah strategi induktif. Dengan strategi induktif, prosedur pembelajaran yang diterapkan dalam penyajian bahan ajar keterampilan berbicara bagi mahasiswa sebagai berikut: pemodelan - telaah model - penerapan model - komentar sebaya komentar dan penguatan oleh pendidik.

Pemodelan berbentuk kegiatan penyajian contoh kegiatan berbicara melalui tayangan video. Bahan yang disajikan disesuaikan dengan capaian pembelajaran yang diharapkan dikuasai peserta didik (mahasiswa). Melalui tayangan video, mahasiswa melakukan pengamatan 
untuk mengidentifikasi dan menganalisis struktur tuturan, ciri pemakaian bahasa yang digunakan oleh pembicara, dan penggunaan unsur ekstralinguistik. Berdasarkan hasil analisisnya, mahasiswa merumuskan struktur tuturan/teks yang didengarnya dan merumuskan ciri-ciri bahasa yang digunakan. Selanjutnya mahasiswa menyusun persiapan kegiatan berbicara untuk dipresentasikan pada pertemuan berikutnya. Pada pertemuan berikutnya, mahasiswa mempraktikkan kegiatan berbicara, mahasiswa lain menyimak untuk dapat memberikan kritik, saran, dan komentar yang disampaikan kepada pembicara. Aspek keterampilan berbicara yang dijadikan sebagai bahan komentar meliputi aspek penguasaan isi/materi pembicaraan, penataan ide/isi pembicaraan, penggunaan bahasa, dan penggunaan aspek ekstralinguistik (gesture, mimik, kontak mata, movement, dan sikap).

\section{Outline Draf Bahan Ajar Keterampilan Berbicara}

Berdasarkan hasil penelitian yang telah dipaparkan, outline bahan ajar keterampilan berbicara bagi mahasiswa sebagai berikut.

\section{BAB I PENDAHULUAN}

- Peranan keterampilan berbicara dalam berkomunikasi sehari-hari dan akademis (keilmuan)

- Pentingnya ketersediaan bahan ajar keterampilan berbicara bagi mahasiswa

- Tujuan penulisan bahan ajar keterampilan berbicara

- Sasaran pengguna bahan ajar keterampilan berbicara

- Struktur isi bahan ajar keterampilan bebicara

\section{BAB II BERBICARA SEBAGAI ASPEK KETERAMPILAN BERBAHASA}

- Aspek-aspek keterampilan berbahasa

- Hubungan antaraspek keterampilan berbahasa

\section{BAB III BERBICARA SEBAGAI KEGIATAN BERKOMUNIKASI}

- Hakikat berbicara

- Proses komunikasi bicara Tujuan berbicara

- Jenis-jenis komunikasi bicara

- Tingkatan keterampilan berbicara

- Faktor penentu komunikasi bicara

- Kiat berbicara efektif

\section{BAB IV BERBICARA DALAM SITUASI TIDAK FORMAL}

- Terampil Bercakap-cakap

- Struktur percakapan lisan

- Karakteristik Bahasa Percakapan

- Terampil Berdialog

- Struktutr Teks Dialog

- Karakteristik Bahasa Teks Dialog

\section{BAB IV BERBICARA INTERPRETATIF}

- Bercerita (autobiografi, biografi, cerpen, legenda, cerita ulang, anekdot, berpantun)

- Struktur Teks Cerita

- Karakteristik Bahasa Cerita

- Membacakan Naskah Drama (Readers Theater)

- Struktur Teks Naskah Drama

- Karakteristik Bahasa Teks Naskah Drama

\section{BAB V BERBICARA FORMAL}

- Melaporkan sesuatu/berita (objek, peristiwa, orang)

- Struktur Teks Laporan

- Karakteristik Bahasa Laporan

- Menjelaskan proses/prosedur

- Struktur Teks Prosedur

- Karakteristik Bahasa Teks Prosedur

- Menyampaikan argumen

- Struktur Teks eksposisi

- Karakteristik Bahasa Teks Eksposisi

- Berwawancara

- Struktur Teks Wawancara

- Karakteristik Bahasa Teks Wawancara

- Berdebat 
- Struktur Teks Debat

- Karakteristik Bahasa Teks Debat

\section{Pembahasan}

Pembahasan dilakukan berdasarkan hasil penelitian yang telah dipaparkan. Hasil penelitian menunjukkan bahwa kebutuhan bahan ajar keterampilan berbahasa Indonesia lisan mahasiswa Program Studi Pendidikan Bahasa dan Sastra Indonesia meliputi bahan ajar yang berbentuk materi teoritis dan materi keterampilan. Materi yang bersifat teoritis mencakup konsepkonsep tentang (a) hakikat berbicara, (b) proses komunikasi bicara, (c) tujuan berbicara, (d) jenis-jenis komunikasi bicara, (e) tingkatan keterampilan berbicara, (f) faktor penentu komunikasi bicara, dan (g) kiat bicara efektif. (2) Materi yang bersifat keterampilan dikategorikan berdasarkan pada konteks situasi komunikasi mulai dari bahan pembelajaran keterampilan berbicara pada situasi informal, interpretatif, formal, dan dramatik. (1) Kategori keterampilan berbicara informal adalah (a) percakapan, (b) mendeskripsikan objek/benda tertentu, dan (c) diskusi. (2) Yang termasuk ke dalam kategori bebicara interpretatif meliputi (a) bercerita dan (b) membacakan drama. (3) Berbicara formal meliputi (a) menyampaikan laporan, (b) berwawancara, dan (c) berdebat. Adapun yang termasuk kategori berbicara dramatik meliputi (a) bermain drama dan (b) bermain peran.

Bahan ajar keterampilan berbicara yang bersifat teoritis diperlukan agar mahasiswa memiliki wawasan dan pemahaman tentang keterampilan berbicara, sehingga dapat dijadikan sebagai bekal untuk meningkatkan keterampilan berbicaranya. Hal ini sesuai dengan capaian pembelajaran yang telah ditetapkan dengan mengacu pada Kerangka Kualifikasi Nasional Indonesia (KKNI) dan Standar Nasional Pendidikan Tinggi (SN Dikti). Dengan mengacu pada kedua sumber tersebut, Asosiasi Program
Studi Pendidikan Bahasa dan Sastra Indonesia telah merumuskan capaian pembelajaran program studi Pendidikan Bahasa dan Sastra Indonesia untuk ranah pengetahuan, "menguasai konsepkonsep dasar keterampilan berbahasa dan bersastra Indonesia". Pemahaman terhadap konsep-konsep dasar tersebut penting karena dapat membantu mengarahkan dan mengontrol penguasaan keterampilan yang diharapkan. Hal itu sesuai dengan pendapat Jarvis (Mulyasa, 2005: 75) bahwa pengetahuan yang dimiliki seseorang berperan membantu memudahkan dalam memahami dan menanggapi pengetahuan baru yang dipelajari.

Selaras dengan pendapat tersebut, penetapan bahan ajar berbentuk konsep teoritis tentang berbicara sesuai dengan kebutuhan pencapaian kompetensi yang telah ditetapkan oleh Asosisasi Program Studi Pendidikan Bahasa dan Sastra Indonesia dengan mengacu pada Standar Nasonal Pendidikan Tinggi (SN Dikti). Di dalam rumusan capaian pembelajaran di tentukan bahwa salah satu capaian pembelajaran untuk mahasiswa strata 1 adalah "menguasai konsep-konsep dasar kebahasaan dan kesastraan, keterampilan berbahasa dan bersastra, pembelajaran bahasa dan sastra, penelitian bahasa dan sastra, serta penelitian pendidikan bahasa dan sastra" (APROBSI, 2016). Hal itu penting untuk dicapai peserta didik karena salah satu profil lulusan Program Studi Pendidikan Bahasa dan Sastra Indonesia Strata 1 adalah menjadi guru. Sebagai guru, di samping dituntut terampil berbicara juga mampu melaksanakan pembelajaran berbicara untuk peserta didik, mulai dari merencanakan, melaksanakan, sampai dengan melaksanakan evaluasi pembelajaran. Kegiatan tersebut memerlukan penguasaan konseptual maupun prosedural tentang keterampilan berbicara. Dengan demikian, bahan ajar yang dikembangkan perlu dilengkapi dengan bahan yang bersifat teoritis. 


\section{KESIMPULAN}

Sesuai dengan masalah dan tujuan penelitian yang telah ditetapkan, hasil penelitian ini disimpulkan bahwa diperlukan bahan ajar keterampilan berbicara yang bersifat teoritis dan pragmatis interaktif. Bahan ajar yang bersifat teoretis diperlukan sebagai bekal pendukung pencapaian kompetensi keterampilan berbahasa. Oleh sebab itu, bahan ajar teoretis konseptual yang disajikan disesuaikan dengan keterampilan yang dikembangkan pada diri mahasiswa.

\section{DAFTAR PUSTAKA}

APROBSI. (2016). Capaian Pembelajaran dan Standar Nasional Pendidikan Bahasa Indonesia. Surakarta: Yuma Pustaka.

Direktorat Sekolah Menengah Pertama. (2006). Pedoman Memilih dan Menyusun Bahan Ajar. Jakarta: Direktorat Jenderal Manajemen Pendidikan Dasar dan Menengah Departemen Pendidikan Nasional.
Gall, M.D; Gall, J.P., \& Borg, W. R. (2003). Educational Research: An Introductioan. Seven Edition. Boston: Pearson Education Inc.

Ghazali, A. S. (2010). Pembelajaran Keterampilan Berbahasa. Bandung: Refika Aditama.

Littlewood, W. (1984). Foreign and Second Language Learning. Cambridge: Cambridge University Press.

Mulyasa. (2005). Manajemen Berbasis Sekolah: Konsep, Strategi, dan Implementasi. Bandung: Remaja Rosdakarya.

Musaba. (2012). Terampil Berbicara, Teori dan Pedoman Penerapanannya. Makasar: Rosdakarya.

Tomlinson, B. (2011). Materials Development in Language Teaching. Cambridge: Cambridge University Press.

Willis, J. (1995). A Recursive, Reflective Instructional Design Model Based on Constructivist-Interpretativist Theory: Educational Technology. Cambridge: Cambridge University Press. 